\title{
Mitochondrial ATP-Synthase Deficiency in a Child with 3-Methylglutaconic Aciduria
}

\author{
ELISABETH HOLME, JOACHIM GRETER, CARL-ERIC JACOBSON, NILS-GÖRAN LARSSON, \\ SVEN LINDSTEDT, KARL OLOF NILSSON, ANDERS OLDFORS, AND MÁR TULINIUS \\ Departments of Clinical Chemistry [E.H., J.G., C.-E.J., N.-G.L., S.L.] and Pathology [A.O.], University of \\ Gothenburg, Sahlgren's Hospital; Department of Pediatrics, University of Gothenburg, East Hospital, \\ Gothenburg, Sweden [M.T.]; and Department of Pediatrics, University of Lund, \\ Malmö General Hospital, Malmö, Sweden [K.O.N.]
}

\begin{abstract}
We report the finding of mitochondrial ATPsynthase deficiency in a child with persistent 3-methylglutaconic aciduria. The child presented in the neonatal period with severe lactic acidosis, which was controlled by Na$\mathrm{HCO}_{3}$ and glucose infusions. During the 1st y of life, there were several episodes of lactic acidosis precipitated by infections or prolonged intervals between meals. The excretion of lactate in urine was variable, but there was a persistent high excretion of 3-methylglutaconic acid. The activity of 3-methylglutaconyl-CoA hydratase in fibroblasts was normal. The child had a hypertrophic cardiomyopathy and magnetic resonance images revealed hypoplasia of corpus callosum. The gross motor and mental development was retarded, but there were no other neurologic signs. Investigation of muscle mitochondrial function at $1 \mathrm{y}$ of age revealed a severe mitochondrial ATP-synthase deficiency (oligomycin-sensitive, dinitrophenol-stimulated $\mathrm{Mg}^{2+}$ ATPase activity: $27 \mathrm{nmol} \times \mathrm{min}^{-1} \times(\mathrm{mg} \text { protein })^{-1}$, control range $223-673 \mathrm{nmol} \times \mathrm{min}^{-1} \times(\mathrm{mg} \text { protein })^{-1}$. The mitochondrial respiratory rate was low and tightly coupled. The respiratory rate was normalized by the addition of an uncoupler. Low $\mathrm{Mg}^{2+}$ ATPase activity was also demonstrated by histochemical methods. Morphologic examination revealed ultrastructural abnormalities of mitochondria. There was no deletion of mitochondrial DNA. The sequences of the ATP synthase subunit genes of mitochondrial DNA were in accordance with published normal sequences. (Pediatr Res 32: 731-735, 1992)
\end{abstract}

\section{Abbreviations}

MELAS, mitochondrial myopathy, encephalopathy, lactic acidosis, and stroke-like episodes

MERRF, myoclonus epilepsy with ragged-red fibers mtDNA, mitochondrial DNA

nt, nucleotide

PCR, polymerase chain reaction

Increased excretion of 3-methylglutaconic acid was reported in two siblings with choreoathetosis, spastic paraparesis, dementia, and optic atrophy (1). Increased excretion of 3-methylglutaconic acid, which is an intermediate in the leucine catabolic pathway, has since been reported in more than 40 cases (2). In 1986, 3-methylglutaconyl-CoA hydratase (EC 4.2.1.18) defi-

Received March 26, 1992; accepted July 7, 1992.

Correspondence and reprint requests: Dr. Elisabeth Holme, Department of Clinical Chemistry, University of Gothenburg, Sahlgren's Hospital, S-413 45 Gothenburg, Sweden.

Supported by Grants 585 and 7122 from the Swedish Medical Research Council and the Göteborg Medical Society. ciency (3) was found in two siblings with this organic aciduria, and recently one additional patient with this enzymatic defect was reported (4). However, in most cases with 3-methylglutaconic aciduria, no enzymatic defect has been identified. In 1983, Barth et al. (5) reported a large family with X-linked cardioskeletal myopathy, neutropenia, and abnormal mitochondria. Recently Kelley et al. (6) reported that a moderately increased excretion of 3-methylglutaconic acid was found in this disorder which they called Barth syndrome. The locus for this disorder has been mapped to Xq28 (7), but the primary defect has not been identified. Other cases with 3-methylglutaconic aciduria and severe neurologic impairment, some with lactic acidosis and/ or cardiac involvement, have been reported, but no enzymatic defect has been identified $(2,8,9)$.

Mitochondrial dysfunction is a cause of lactic acidosis in children, and cardiomyopathy is one of the manifestations of mitochondrial disorders $(10,11)$. Deficiencies of NADH: ubiquinone reductase (EC 1.6.5.3) (12-16), ubiquinol:cytochrome $c$ reductase (EC 1.10.2.2) (17), and cytochrome $c$ oxidase (EC 1.9.3.1) (18-20) have all been reported to be associated with cardiomyopathy in childhood. Cytochrome $c$ oxidase deficiency alone $(18-20)$ or combined with NADH:ubiquinone reductase deficiency $(21-25)$ seems to be the most frequent finding. Mitochondrial ATP-synthase (EC 3.6.1.34) deficiency seems to be an extremely rare cause of oxidative phosphorylation impairment. It has only been reported in a 37 -y-old woman with a hypertrophic cardiomyopathy who had suffered from a nonprogressive muscle weakness since childhood (26).

We report a child with 3-methylglutaconic aciduria, intermittent severe lactic acidosis and cardiomyopathy with severe mitochondrial ATP-synthase deficiency.

\section{CASE REPORT}

This girl was the third child of healthy nonconsanguineous parents, who were gypsies from Yugoslavia. The older children were healthy. The child was born at term. The delivery was normal. The birth weight was $2.2 \mathrm{~kg}$. At $15 \mathrm{~h}$ she developed respiratory distress and a severe metabolic acidosis. At $2 \mathrm{~d}$, investigation of organic acids in urine by gas chromatography/ mass spectrometry revealed a severe lactic acidosis $(55 \mathrm{~mol} / \mathrm{mol}$ creatinine), slight ketoacidosis, and moderately increased excretion of 3-methylglutaric and 3-methylglutaconic acid (43 and $156 \mathrm{mmol} / \mathrm{mol}$ creatinine). The metabolic acidosis was controlled by $\mathrm{NaHCO}_{3}$ and glucose infusions. Oral feeding was gradually introduced. At $1 \mathrm{mo}$, she had started to gain weight. The muscle tone was normal and she made good eye contact. She had no acidosis, but the lactate excretion was slightly increased. The excretion of 3-methylglutaric and 3-methylglutaconic acid persisted. At $4 \mathrm{mo}$, a hypertrophic cardiomyopathy was found. During her 1st y of life, she had several episodes of 
lactic acidosis that were precipitated by infection or prolonged intervals between meals. There was no hypoglycemia.

At 1 y of age, she was investigated for a mitochondrial disorder. Her weight was $5.9 \mathrm{~kg}$. Muscle tone and mass were diminished. The gross motor development was at the level of 5-6 mo and fine motor and mental development at the level of 8-9 mo. The electroencephalography was normal, and there were no seizures or other neurologic signs. Magnetic resonance images showed hypoplasia of the splenium part of corpus callosum and slightly enlarged basal cisterns and ventricles. Fasting blood lactate concentration was increased to $3.4 \mathrm{mmol} / \mathrm{L}$. The lactate:pyruvate ratio was increased to 28.6 . The cerebrospinal fluid lactate concentration was $5.0 \mathrm{mmol} / \mathrm{L}$, and the pyruvate concentration was $206 \mu \mathrm{mol} / \mathrm{L}$. The cerebrospinal fluid protein concentration was slightly increased to $420 \mathrm{mg} / \mathrm{L}$ (reference interval 150-300). The total carnitine concentration in serum was high, $66 \mu \mathrm{mol} / \mathrm{L}$ (reference interval 23-60 $\mu \mathrm{mol} / \mathrm{L}$ ), and the acylated fraction was slightly increased to $16 \mu \mathrm{mol} / \mathrm{L}$ (reference interval $<20 \%$ of the total carnitine concentration). Muscle carnitine concentration was normal, $16 \mu \mathrm{mol} \times \mathrm{g}$ protein $^{-1}$ (reference interval 7.4-26 $\mu \mathrm{mol} \times \mathrm{g}_{\text {protein }}{ }^{-1}$ ). There were no signs of liver involvement, and serum aspartate aminotransferase and alanine aminotransferase were within the reference interval. Plasma prothrombin complex, ammonium ion, and amino acid concentrations were normal. Routine hematology, including neutrophil counts, were normal.

\section{MATERIALS AND METHODS}

A skeletal muscle specimen was obtained from the vastus lateralis muscle with the patient under general anesthesia. Morphologic examination, including enzyme histochemical and ultrastructural analysis of muscle tissue, was performed as described (10). Enzyme histochemical staining for mitochondrial $\mathrm{Mg}^{2+}$ ATPase was performed as described (27). Biochemical investigation of the respiratory chain function was done on isolated intact muscle mitochondria with polarographic measurements as described $(10,28)$ and in disrupted isolated mitochondria by spectrophotometric methods as described (10). Control biopsy specimens were from children investigated for suspected neuromuscular disease or undergoing orthopedic surgery. The diseases in these children were of nonmitochondrial origin, and there were no major morphologic or histochemical changes in the biopsy specimens (10). ATP-synthase activity was measured as the dinitrophenol-activated and oligomycin-sensitive ATPase activity in isolated muscle mitochondria according to Barth et al. (5).

DNA was isolated from muscle, blood, and fibroblasts from the patient, and mtDNA was analyzed by Southern blotting as previously described (29). The point mutation at nt 8344 (30) associated with MERRF syndrome was analyzed with PCR (31). The point mutation at nt 3243 associated with MELAS syndrome was analyzed with $A p a$ I digestion and Southern blotting (32). The point mutation at nt 8993 associated with retinitis pigmentosa, and ataxia was analyzed with $A v a l$ digestion and Southern blotting (33). Muscle DNA from the patient was used for mtDNA sequencing. The asymmetric primer method (34) was used to generate single-stranded DNA corresponding to the genes for ATP-synthase subunits 8 and 6 . The single-stranded DNA was used either for direct sequencing as previously described (35) or for cyclic sequencing with the Taq DyeDeoxy Terminator Cycle Sequencing Kit and the 373A DNA Sequencer (Applied Biosystems Inc., Foster City, CA) under conditions recommended by the manufacturer. About $95 \%$ of the sequence was obtained by direct sequencing and the remaining $5 \%$ by cyclic sequencing. Primers corresponding to nt 8301-8320 (NG48), 8327-8346 (NG50), 8475-8494 (NG52), 8681-8700 (NG53), 8901-8920 (NG54), and 9106-9125 (NG55) of the heavy strand and nt 9250-9270 (NG49), 9228-9247 (NG51), 9030-9050 (NG56), 8835-8854 (NG57), 8585-8604 (NG58), and 8451-8470
(NG59) of the light strand of mtDNA were synthesized with a PCR Mate 391 DNA Synthesizer (Applied Biosystems Inc.). The primer pairs NG48/NG49, NG48/NG57, and NG53/NG49 were used for asymmetric PCR. The primers NG50-NG59 were used as sequencing primers. Numbering of mtDNA nucleotides was done according to the Cambridge human mtDNA sequence (36).

The activity of 3-methylglutaconyl-CoA hydratase in fibroblasts was measured by a coupled assay according to Gibson et al. (37). [5- $\left.{ }^{14} \mathrm{C}\right]-3-$ methylglutaconyl-CoA was generated by endogenous 3-methylcrotonyl-CoA carboxylase from 3-methylcrotonyl-CoA, ATP, and $\mathrm{NaH}^{14} \mathrm{CO}_{3}$. 3-Hydroxybutyrate dehydrogenase and NADH were included in the assay, and formed $\left[1-{ }^{14} \mathrm{C}\right]-3$-hydroxybutyrate was isolated by HPLC.

Organic acids were isolated from urine as described (38) and analyzed by gas chromatography/mass spectrometry on a TRIO-1 quadrupole mass spectrometer-data system (Fisons Instruments Nordic AB, Solna, Sweden) connected via an open split interface (Scientific Glass Engineering, Melbourne, Australia) to a Mega5160 gas chromatograph with on-column injector, CP-CF5 16 flow regulator, and AS550 autosampler (Fisons Instruments Nordic AB, Solna, Sweden). The gas-chromatographic capillary columns used were $30 \mathrm{~m}$ long, $0.33-\mathrm{mm}$ inner diameter open tubular fused silica columns coated with $0.5 \mu \mathrm{m}$ cross-linked SE-54 (Skandinaviska GeneTec AB, Kungsbacka, Sweden). Quantification of organic acids from reconstructed specific ion traces were done as described (38) using the LabBase software (Fisons Instruments Nordic AB, Solna, Sweden).

\section{RESULTS}

Initially, the severe neonatal lactic acidosis was the most impressive finding in this case. Slightly to moderately increased excretion of various other metabolites are often seen in critically ill infants, and initially the excretion of 3-methylglutaconic acid was regarded to be insignificant. It soon became evident that the increased excretion of 3-methylglutaconic acid was a constant finding, whereas there was a great variability in the amount of lactate excreted (Table 1).

3-Methylglutaconyl-CoA hydratase deficiency was excluded by measurement of 3-hydroxybutyrate production from 3-methylcrotonyl-CoA and ${ }^{14} \mathrm{C}$-labeled bicarbonate in fibroblast extracts. The enzyme activity was measured at three different occasions. The mean activity in the patient was $102 \mathrm{pmol} \times$ $\mathrm{min}^{-1} \times\left(\mathrm{mg}\right.$ protein $\left.{ }^{-1}\right)($ range 58-156). In 11 controls, the mean activity was $145 \mathrm{pmol} \times \mathrm{min}^{-1} \times\left(\mathrm{mg}\right.$ protein $\left.{ }^{-1}\right)($ range $83-348)$.

The intermittent lactic acidosis and the finding of a hypertrophic cardiomyopathy at 4 mo of age prompted an investigation for an oxidative phosphorylation disorder. At 1 y of age, a muscle biopsy was performed. The respiratory rate of isolated intact mitochondria was decreased in the presence of all substrates tested. The respiratory rate was normalized in the presence of an uncoupler (Table 2). The activities of the different parts of the respiratory chain measured in disrupted mitochondria were found to be normal (Table 3 ). The respiratory rate thus seemed to be limited by the coupling to ATP-synthesis. In accordance with this, a deficiency of ATP-synthase activity was found. The activity was measured as the DNP-stimulated oligomycin-sensitive $\mathrm{Mg}^{2+}$ ATPase activity in intact mitochondria (Table 4).

The histochemical investigation was in accordance with the biochemical measurements, and no detectable mitochondrial ATPase activity was found (Fig. 1), whereas normal cytochrome $c$ oxidase and succinate dehydrogenase activities were found. Electron microscopy revealed abnormal mitochondria (Fig. 2).

The genes for ATP-synthase subunits 8 and 6 of mtDNA in muscle were sequenced and compared with the Cambridge human mtDNA sequence (36). We found a mutation that changes an adenine to guanine at nt 8860 and results in an amino acid replacement in subunit 6 . This mutation has been reported in several patients with different neuromuscular disorders and also 
Table 1. Organic acids in urine

\begin{tabular}{lccc}
\hline Age & $\begin{array}{c}\text { Lactate } \\
\text { (mol/mol creatinine) }\end{array}$ & $\begin{array}{c}\text { 3-Methylglutaconate } \\
\text { (mmol/mol creatinine) }\end{array}$ & $\begin{array}{c}\text { 3-Methylglutarate } \\
\text { (mmol/mol creatinine) }\end{array}$ \\
\hline $2 \mathrm{~d}$ & 55 & 156 & 43 \\
$3 \mathrm{wk}$ & 0.05 & 167 & 50 \\
$5 \mathrm{wk}$ & 4.8 & 135 & 41 \\
$2 \mathrm{mo}$ & 0.02 & 91 & 25 \\
$3.5 \mathrm{mo}$ & 0.03 & 120 & 20 \\
$7 \mathrm{mo}$ & 9.1 & 277 & 39 \\
$12 \mathrm{mo}$ & $<0.02$ & 236 & 83 \\
$14 \mathrm{mo}$ & $<0.02$ & 222 & 71 \\
$15 \mathrm{mo}$ & 0.03 & $<20$ & $<8$ \\
Reference & $<0.02$ & & $<20$ \\
interval & & $<$ & \\
\hline
\end{tabular}

Table 2. Oximetric measurements of respiratory rate in isolated muscle mitochondria

\begin{tabular}{|c|c|c|c|}
\hline \multirow[b]{3}{*}{ Substrate } & \multicolumn{3}{|c|}{$\begin{array}{l}\text { Respiratory rate } \\
{\left[\mathrm{nmol} \mathrm{O} \times \mathrm{min}^{-1} \times\right.} \\
\left.(\mathrm{mg} \text { protein })^{-1}\right]\end{array}$} \\
\hline & \multirow[b]{2}{*}{ Patient } & \multicolumn{2}{|c|}{$\begin{array}{l}\text { Controls } \\
(n=10)\end{array}$} \\
\hline & & Mean & Range \\
\hline Pyruvate + malate & 23 & 98 & $86-116$ \\
\hline Succinate + rotenone & 42 & 99 & $76-117$ \\
\hline Succinate + rotenone + DNP* & 122 & & \\
\hline Ascorbate + TMPD $\dagger$ & 159 & 251 & $207-302$ \\
\hline
\end{tabular}

*2,4-Dinitrophenol, $125 \mu \mathrm{mol} / \mathrm{L}$.

$\dagger \mathrm{N}, \mathrm{N}, \mathrm{N}^{\prime}, \mathrm{N}^{\prime}$-tetramethyl-p-phenylenediamine, $500 \mu \mathrm{mol} / \mathrm{L}$.

Table 3. Respiratory chain enzyme activities in isolated muscle mitochondria

\begin{tabular}{lrrc}
\hline & \multicolumn{3}{c}{ Enzyme activity } \\
\cline { 2 - 4 } & & \multicolumn{2}{c}{$\begin{array}{c}\text { Controls } \\
(n=10)\end{array}$} \\
\cline { 2 - 4 } & Patient & Mean & Range \\
\hline NADH-ferricyanide reductase* & 5900 & 6700 & $4500-8600$ \\
Succinate cytochrome $c$ reduc- & 340 & 300 & $160-400$ \\
$\quad$ tase* & 2700 & 2400 & $2000-3500$ \\
Citrate synthase* & 13 & 11 & $6.1-15$ \\
\hline Cytochrome $c$ oxidase $\dagger$ & \multicolumn{3}{c}{} \\
\hline
\end{tabular}

$*$ nmol $\times \min ^{-1} \times(\mathrm{mg} \text { protein })^{-1}$.

$\dagger$ Rate constant $(k) \mathrm{min}^{-1} \times(\mathrm{mg} \text { protein })^{-1}$.

Table 4. ATP-synthase ( $\mathrm{Mg}^{2+}$ ATPase) activity in isolated muscle mitochondria*

\begin{tabular}{cccc}
\hline & \multicolumn{3}{c}{$\begin{array}{c}\text { ATP-synthase activity } \\
{\left[\mathrm{nmol} \times \mathrm{min}^{-1} \times(\mathrm{mg} \text { protein })^{-1}\right]}\end{array}$} \\
\cline { 2 - 4 } & & \multicolumn{3}{c}{$\begin{array}{c}\text { Controls } \\
(n=10)\end{array}$} \\
\cline { 2 - 4 } Additions & Patient & Mean \pm SD & Range \\
\hline +DNP-oligomycin & 27 & $452 \pm 179$ & $223-673$ \\
-DNP-oligomycin & 24 & $36 \pm 21$ & $0-72$ \\
+DNP+oligomycin & 24 & $32 \pm 16$ & $0-57$ \\
\hline
\end{tabular}

* DNP, 2,4-dinitrophenol.

in healthy subjects. It probably represents an error in the Cambridge mtDNA sequence $(30,39)$. No other mutations were found. Southern blot analysis revealed no mtDNA deletions. The point mutations associated with MERRF, MELAS, and retinitis pigmentosa and ataxia syndromes were not found.
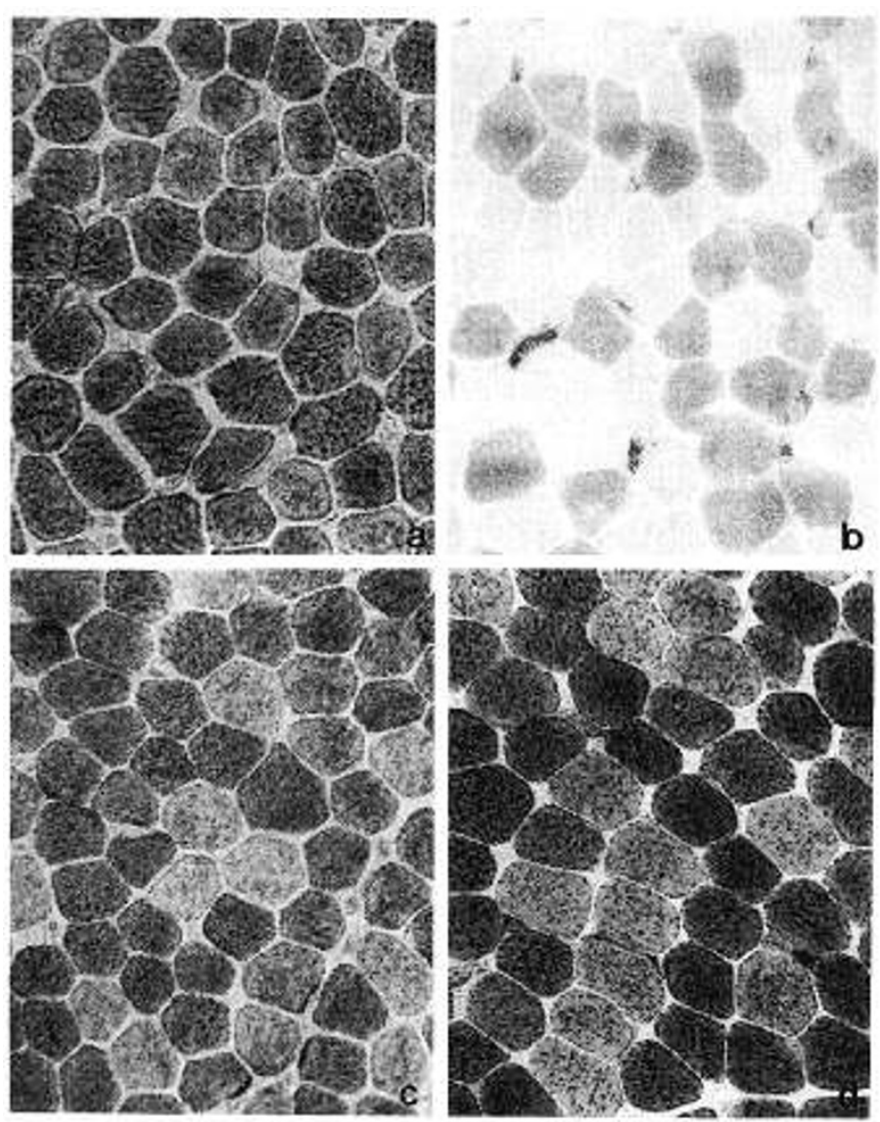

Fig. 1. Enzymehistochemical staining of cytochrome $c$ oxidase ( $a$ and c) and $\mathrm{Mg}^{2+}$ ATPase ( $b$ and $d$ ) of skeletal muscle from the patient ( $a$ and $b$ ) and a control case ( $c$ and $d$ ). The particulate staining of mitochondria in the muscle fibers is absent in the patient after incubation for $\mathrm{Mg}^{2+}$ ATPase $(b)$.

\section{DISCUSSION}

An isolated ATP-synthase deficiency has for the first time been identified in a child with hypertrophic cardiomyopathy, and a new enzymatic defect has been connected with 3-methylglutaconic aciduria. The family history of the patient was uninformative. We have made a thorough investigation of mtDNA, including sequencing of the mtDNA genes coding for the ATPsynthase subunits 6 and 8 , and no deviations from known normal sequences were found. The congenital disorder of the girl is thus most probably an inherited autosomal recessive disorder, which may be due to a mutation in one of the probable 11 nuclear DNA-encoded subunits of ATP-synthase $(40,41)$.

ATP-synthase deficiency has only been reported in one previous case (26). This was a 37-y-old woman with a nonprogressive muscular weakness since childhood. There were no signs of 

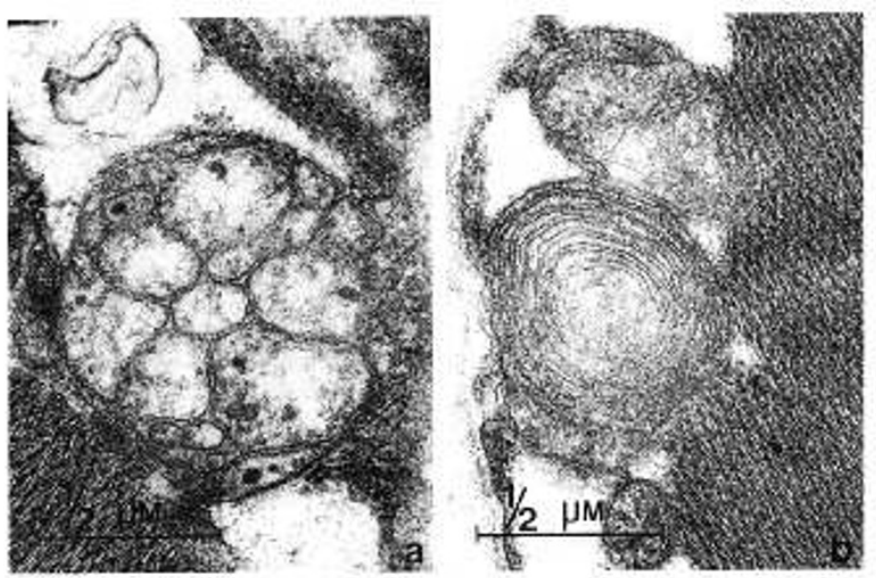

Fig. 2. Electron microscopy of abnormal mitochondria in the skeletal muscle showing abnormal arrangements of cristae.

encephalopathy. A point mutation of the ATP synthase subunit 6 gene of mitochondrial DNA has been found in a family with retinitis pigmentosa and ataxia (33). The ATP synthase activity in this family was not reported. It is thus not known if the phenotype of this family was linked to ATP synthase deficiency. The major problem in our case has been several episodes of severe lactic acidosis. These episodes were precipitated when intervals between meals were prolonged, and they were controlled by frequent feeding. The intolerance to fasting may indicate liver involvement, but there were no other findings that supported the possibility of liver disease. The increased lactate, pyruvate, and protein concentration in cerebrospinal fluid indicates involvement of the CNS. The child also had hypoplasia of corpus callosum. This has been reported in another case with 3methylglutaconic aciduria (42). Malformations of the brain, including abnormalities of corpus callosum, are frequently found in pyruvate dehydrogenase deficiency (43) and may be caused by deficient energy metabolism. The clinical course in the previously reported case with ATP-synthase deficiency was rather benign (26). At present, the clinical course in our patient is uneventful. There has been no progress in the cardiac disease, and there have been no signs of a progressive encephalopathy. However, a future development of a progressive encephalopathy cannot be excluded, since there are signs of CNS involvement.

We cannot see an obvious connection between accumulation of 3-methylglutaconic acid and ATP-synthase deficiency. In our experience, 3-methylglutaconic aciduria is not a general finding in mitochondrial disorders. We have reported the results of extensive investigations of 50 children with suspected mitochondrial disorders (10). A mitochondrial disorder was verified in 20 of these patients. There was a record of increased excretion of 3methylglutaconic acid in urine in two of these patients. At the time of the mitochondrial investigation, the excretion was normal in one of these patients and too modest to merit a diagnosis of an organic aciduria in the other patient. The first case had Kearns-Sayre syndrome. He was included in the study at $17 \mathrm{y}$ of age at an advanced stage of the disease. A normal respiratory rate was found in the isolated mitochondrial preparation $(10$, 29). He died at 19 y of age in cardiorespiratory failure (44). The other case was a 6-y-old boy with a MERRF-like syndrome with generally deranged respiratory chain function. He had no signs of cardiac or liver involvement $(10,11)$. ATP synthase was not measured at the time, but histochemical analysis of a frozen muscle sample revealed normal mitochondrial ATPase activity. ATP-synthase activity was measured in the last 31 patients in the published series $(10,11)$. This series included patients with mtDNA deletions and the point mutations of MERRF and MELAS syndromes and patients with cardiomyopathy. In none of these patients was an ATP-synthase deficiency that would limit ATP synthesis found. Increased excretion of 3-methylglu- taconic acid is thus neither a sign of impaired respiratory chain function in general nor a specific sign of ATP-synthase deficiency.

Mitochondrial cardiomyopathy is found in many patients with increased excretion of 3-methylglutaconic acid, e.g. in Barth syndrome (5), but 3-methylglutaconic aciduria is not a general finding in mitochondrial cardiomyopathy. 3-Methylglutaconic acid is an intermediate in the leucine-catabolic pathway. In patients with 3-methylglutaconic aciduria, which is not caused by 3-methylglutaconyl-CoA hydratase deficiency, the effect on the excretion of 3-methylglutaconate of leucine loads and leucine restriction has been reported. In some cases, moderately increased excretion has been found $(1,42,45)$, but in most patients, e.g. those with Barth syndrome (6), the excretion seems to be independent of the dietary intake of leucine. Our patient was not given a leucine load or a leucine-restricted diet, but a remarkably constant level of excretion was found both in situations of metabolic stress and in situations of metabolic balance. This indicates that the excretion is independent of leucine catabolism. 3-Methylglutaconate is also involved in isoprenoid metabolism via the mevalonate shunt pathway (46). This pathway is proposed to account for significant metabolism of mevalonate to $n$-fatty acids and carbon dioxide. Increased flow or perturbation of this pathway, which may include metabolism of farnesyl pyrophosphate or other isoprenoid structures, may account for increased urinary excretion of 3-methylglutaconic acid. The most obvious connection between mitochondrial disorders and isoprenoid metabolism is ubiquinone (coenzyme Q), which is synthesized in the inner mitochondrial membrane by transfer of a polyprenylpyrophosphate to 4-hydroxybenzoate to form 3-decaprenyl-4hydroxybenzoate (47), which then is hydroxylated, decarboxylated, and methylated to form ubiquinone. A perturbation of this synthesis could lead to increased degradation of, e.g., polyprenylpyrophosphate and an increased production and excretion of 3-methylglutaconic acid.

Many patients with 3-methylglutaconic aciduria have signs and symptoms compatible with mitochondrial disorders. We have identified a specific mitochondrial disorder in a patient with 3-methylglutaconic aciduria. We do not think that 3-methylglutaconic aciduria is a specific sign of ATP-synthase deficiency, but rather a sign of a specific disturbance, which is caused by deficient oxidative phosphorylation.

\section{REFERENCES}

1. Greter J, Hagberg B, Steen G, Söderhjelm U 1978 3-Methylglutaconic aciduria: report on a sibship with infantile progressive encephalopathy. Eur J Pediat 129:231-238

2. Gibson KM, Sherwood WG, Hoffmann GF, Stumpf DA, Dianzani I, Schutgens RBH, Barth PG, Weismann U, Bachmann C, Schrynermackers-Pitance P Verloes A, Narisawa K, Mino M, Ohya N, Kelley RI 1991 Phenotypic heterogeneity in the syndromes of 3-methylglutaconic aciduria. J Pediat 118:885-890

3. Narisawa K, Gibson KM, Sweetman L, Nyhan WL, Duran M, Wadman SK 1986 Deficiency of 3-methylglutaconyl-coenzyme A hydratase in two siblings with 3-methylglutaconic aciduria. J Clin Invest 77:1148-1152

4. Gibson KM, Lee CF, Wappner RS 1991 3-Methylglutaconyl-coenzyme A hydratase deficiency: a new case. Abstracts of the 29th SSIEM annual symposium (abstr P-135)

5. Barth PG, Scholte HR Berden JA, van der Klei-van Moorsel JM, LuytHouwen IEM, van't Veer-Korthof ET, van der Harten JJ, Sobotka-Plojhar MA 1983 An X-linked mitochondrial disease affecting cardiac muscle, skeletal muscle and neutrophil leucocytes. J Neurol Sci 62:327-355

6. Kelley RI, Cheatham JP, Clark BJ, Nigro MA, Powell BR, Sherwood GW, Sladky JT, Swisher WP 1991 X-linked dilated cardiomyopathy with neutropenia, growth retardation, and 3-methylglutaconic aciduria. J Pediatr 119:738-747

7. Bolhuis PA, Hensels GW, Hulsebos TJM, Baas F, Barth PG 1991 Mapping of the locus for X-linked cardioskeletal myopathy with neutropenia and abnormal mitochondria (Barth syndrome) to Xq28. Am J Hum Genet 48:481485

8. Largilliere C, Vallee L, Cartigny B, Dubos JP, Gibson KM, Nuyts JP, Farriaux JP 1989 3-Methylglutaconic aciduria: neonatal onset with lactic acidosis. J Inherited Metab Dis 12:333-334

9. Elpeleg ON, Meiron D, Barash V, Hurwitz Y, Tal I, Amir N 1990 3-Methylglutaconic aciduria with a persistent metabolic acidosis and 'uncoupling episodes'. J Inherited Metab Dis 13:235-236 
10. Tulinius MH, Holme E, Kristiansson B, Larsson N-G, Oldfors A 1991 Mitochondrial encephalomyopathies in childhood. I. Biochemical and morphological investigations. J Pediatr 119:242-250

11. Tulinius MH, Holme E, Kristiansson B, Larsson N-G, Oldfors A 1991 Mitochondrial encephalomyopathies in childhood. II. Clinical manifestations and syndromes. J Pediatr 119:251-259

12. Hoppel CL, Kerr DS, Dahms B, Roessmann U 1987 Deficiency of the reduced nicotinamide adenine dinucleotide dehydrogenase component of complex I of mitochondrial electron transport. J Clin Invest 80:71-77

13. Kobayashi M, Morishita $H$, Sugiyama N, Yokochi K, Nakano M, Wada Y, Hotta Y, Terauchi A, Nonaka I 1987 Two cases of NADH-coenzyme Q reductase deficiency: relationship to MELAS syndrome. J Pediatr 110:223227

14. Tanaka M, Nishikimi M, Suzuki H, Ozawa T, Nishizawa M, Tanaka K, Miyatake T 1986 Deficiency of subunits in heart mitochondrial NADHubiquinone oxidoreductase of a patient with mitochondrial encephalomyopathy and cardiomyopathy. Biochem Biophys Res Commun 140:88-93

15. Nishizawa $M$, Tanaka K, Shinozawa, Kuwabara T, Atsumi T, Miyatake T, Ohama E 1987 A mitochondrial encephalomyopathy with cardiomyopathy. A case revealing a defect of complex $I$ in the respiratory chain. J Neurol Sci 78:189-201

16. Ichiki T, Tanaka M, Nishikimi M, Suzuki H, Ozawa T, Kobayashi M, Wada Y 1988 Deficiency of subunits of complex I and mitochondrial encephalomyopathy. Ann Neurol 23:287-294

17. Papadimitriou A, Neustein HB, DiMauro S, Stanton R, Bresolin N 1984 Histocytoid cardiomyopathy of infancy: deficiency of reducible cytochrome $b$ in heart mitochondria. Pediatr Res 18:1023-1028

18. Rimoldi M, Bottachi E, Rossi L, Cornelio F, Uziel G, DiDonato S 1982 Cytochrome $c$ oxidase deficiency in muscles of a floppy infant without mitochondrial myopathy. J Neurol 227:201-207

19. Sengers RCA, Trijbels JMF, Bakkeren JAJM, Ruitenbeek W, Fischer JC, Janssen AJM, Stadhouders AM, ter Laak HJ 1984 Deficiency of cytochrome $b$ and $a a_{3}$ in muscle from a floppy infant with cytochrome oxidase deficiency. Eur J Pediatr 141:178-180

20. Zeviani M, van Dyke DH, Servidei S, Bauserman SC, Bonilla E, Beaumont ET, Sharda J, van der Laan K, DiMauro S 1986 Myopathy and fatal cardiopathy due to cytochrome $c$ oxidase deficiency. Arch Neurol 43:11981202

21. Böhles HS, Singer H, Ruitenbeek W, Trijbels JMF, Sengers RCA, Ketelsen UP, Wagner-Thiessen E, Wick H 1987 Foamy myocardial transformation in a child with a disturbed respiratory chain. Eur J Pediatr 146:582-586

22. Zheng X, Shoffner JM, Lott MT, Voljavec AS, Krawiecki NS, Winn K, Wallace DC 1989 Evidence in a lethal infantile mitochondrial disease for a nuclear mutation affecting respiratory complexes I and IV. Neurology 39:1203-1209

23. Tulinius MH, Eriksson BO, Hjalmarsson O, Holme E, Oldfors A 1989 Mitochondrial myopathy and cardiomyopathy in siblings. Pediatr Neurol 5:182188

24. Oldfors A, Sommerland H, Holme E, Tulinius M, Kristiansson B 1989 Cytochrome $c$ oxidase deficiency in infancy. Acta Neuropathol (Berl) 77:267-275

25. Tanaka $\mathrm{M}$, Ino $\mathrm{H}$, Ohno $\mathrm{K}$, Hattori $\mathrm{K}$, Sato $\mathrm{W}$, Ozawa $\mathrm{T}$, Tanaka $\mathrm{T}$, Itoyama S 1990 Mitochondrial mutation in fatal infantile cardiomyopathy. Lancet $336: 1452$

26. Schotland DL, DiMauro S, Bonilla E, Scarpa A, Lee C-P 1976 Neuromuscular disorder associated with a defect in mitochondrial energy supply. Arch Neurol 33:475-479

27. Meijer AEFH, Vloedman AHT 1980 The histochemical characterization of the coupling state of skeletal muscle mitochondria. Histochemistry 69:217232

28. Scholte HR, Busch HFM, Luyt-Houwen IEM 1981 Functional disorders of mitochondria in muscular diseases-respiratory chain phosphorylation-the carnitine system. In: Busch HFM, Jennekens FG, Scholte HR (eds) Mitochondria and Muscular Diseases. Mefar b.v. Beetsterzwaag, The Netherlands, pp 133-145

29. Larsson N-G, Holme E, Kristiansson B, Oldfors A,' Tulinius M 1990 Progressive increase of the mutated mitochondrial DNA fraction in Kearns-Sayre syndrome. Pediatr Res 28:131-136

30. Shoffner JM, Lott MT, Lezza AMS, Seibel P, Ballinger SW, Wallace DC 1990 Myoclonic epilepsy and ragged-red fiber disease (MERRF) is associated with a mitochondrial DNA tRNA ${ }^{\text {Lys }}$ mutation. Cell 61:931-937

31. Zeviani M, Amati P, Bresolin N, Antozzi C, Piccolo G, Toscano A, DiDonato $S 1991$ Rapid detection of the $A \rightarrow G^{(8344)}$ mutation of mtDNA in Italian families with myoclonus epilepsy and ragged-red fibres (MERRF). Am J Hum Genet 48:203-211

32. Goto Y-i, Nonaka I, Horal S 1990 A mutation in the tRNA ${ }^{\text {Leu(UUR) }}$ gene associated with the MELAS subgroup of mitochondrial encephalomyopathies. Nature 348:651-652

33. Holt IJ, Harding AE, Petty RKH, Morgan-Hughes JA 1990 A new mitochondrial disease associated with mitochondrial DNA heteroplasmy. Am J Hum Genet 46:428-433

34. Gyllensten UB, Erlich HA 1988 Generation of single-stranded DNA by the polymerase chain reaction and its application to direct sequencing of the HLA-DOA locus. Proc Natl Acad Sci USA 85:7652-7656

35. Larsson N-G, Andersen O, Holme E, Oldfors A, Wahlström J 1991 Leber's hereditary optic neuropathy and complex I deficiency in muscle. Ann Neurol 30:701-708

36. Anderson S, Bankier AT, Barrell BG, de Bruijn MHL, Coulson AR, Drouin J Eperon IC, Nierlich DP, Roe BA, Sanger F, Schreier PH, Smith AJH, Staden $R$, Young IG 1981 Sequence and organization of the human mitochondrial genome. Nature 457-465

37. Gibson KM, Nyhan WL, Sweetman L, Narisawa K, Lehnert W, Divry P, Robinson BH, Roth KS, Beemer FA, van Sprang FJ, Duran M, Wadman SK, Cartigny B 1988 3-Methylglutaconic aciduria: a phenotype in which activity of 3-methylglutaconyl-coenzyme A hydratase is normal. Eur J Pediatr 148:76-82

38. Greter J, Jacobson C-E 1987 Urinary organic acids: isolation and quantification for routine metabolic screening. Clin Chem 33:473-480

39. Ozawa T, Tanaka M, Ino H, Ohno K, Sano T, Wada Y, Yoneda M, Tanno Y, Miyatake T, Tanaka T, Itoyama S, Ikebe S-i, Hattori N, Mizuno Y 1991 Distinct clustering of point mutations in mitochondrial DNA among patients with mitochondrial encephalomyopathies and with Parkinson's disease. Biochem Biophys Res Commun 176:938-946

40. Hatefi Y 1985 The mitochondrial electron transport and oxidative phosphorylation system. Ann Rev Biochem 54:1015-1069

41. Hekman C, Tomich JM, Hatefi Y 1991 Mitochondrial ATP synthase complex. J Biol Chem 266:13564-13571

42. Lehnert W, Scharf J, Wendel U 1985 3-Methylglutaconic and 3-methylglutaric aciduria in a patient with suspected 3-methylglutaconyl-CoA hydratase deficiency. Eur J Pediatr 143:301-303

43. Robinson BH 1989 Lactic acidemia. In: Scriver CR, Beaudet AL, Sly WS, Valle D (eds) The Metabolic Basis of Inherited Disease, McGraw-Hill, New York, pp, 869-888

44. Oldfors A, Fyhr I-M, Holme E, Larsson N-G, Tulinius M 1990 Neuropathology in Kearns-Sayre syndrome. Acta Neuropathol (Berl) 80:541-546

45. Hagberg B, Hjalmarsson O, Lindstedt S, Ransnäs L, Steen G 1983 3-Methylglutaconic aciduria in two infants. Clin Chim Acta 134:59-67

46. Landau BR, Brunengraber H 1985 Shunt pathway of mevalonate metabolism. Methods Enzymol 110:100-114

47. Gupta A, Rudney H 1985 4-Hydroxybenzoate polyprenyltransferase from rat liver. Methods Enzymol 110:327-334 